\title{
MANIFESTACIONES Y LÍMITES DE LA BUENA FE OBJETIVA EN LA EJECUCIÓN DE LOS CONTRATOS. CRITERIOS JURÍDICOS PARA LA RESOLUCIÓN DE SITUACIONES CONTRACTUALES DIFUSAS
}

\author{
MANIFESTATIONS AND LIMITS OF OBJECTIVE GOOD FAITH \\ IN THE EXECUTION OF CONTRACTS. LEGAL CRITERIA FOR \\ THE RESOLUTION OF DIFFUSE CONTRACTUAL SITUATIONS
}

FABIÁN ELORRIAGA DE BONIS ${ }^{*}$

\section{Resumen}

La buena fe no es solo un principio informador del ordenamiento jurídico en general y de los contratos en particular, sino que se configura como un deber de comportamiento típico que la ley impone a los contratantes. Esto se manifiesta en el nacimiento de una serie de deberes contractuales de comportamiento, denominados deberes implícitos, colaterales, implied terms, prestaciones virtuales o figuras parcelares de la buena fe, todos los que no están expresamente previstos en el contrato como obligaciones de las partes, pero que derivan de la buena fe y sirven para decidir situaciones contractuales difusas. Con todo, la buena fe no es un recurso que carezca de límites, ya que salvo que existan buenas razones para ello, estos relevantes deberes no pueden invocarse para eludir lo claramente estipulado en el contrato, y ellos podrán alegarse con sustento sólo para integrarlo donde no existió suficiente previsión o lo estipulado no es armónico o coherente con las circunstancias de hecho que rodean su ejecución y la finalidad económica de las partes.

1 * Profesor titular de Derecho Civil, Universidad Adolfo Ibáñez (Viña del Mar), Chile. Mail: felorria@uai.cl 


\title{
Palabras clave
}

Buena fe contractual - manifestaciones - límites

\begin{abstract}
Good faith is not only a general principle of Law and contracts in particular, but also constitutes a duty of typical behavior that the parties are bound to follow by law. This translates in the existence of a number of contractual duties, that are called implicit duties, collaterals, implied terms, virtual obligations or parcel figures of good faith, all of which are not expressly stated in the contract as parties' obligations but that derive from good faith and serve to decide unclear contractual problems. However, good faith is not a resource that lacks limits since, unless there is good reasons for doing so, such duties cannot be invoked to avoid what is clearly stated in the contract, thence the same can only be soundly used in order to fulfill what was not foreseen or what was stated in the contract is not harmonic or coherent with the factual circumstances that surround its execution and the economic goals of the parties.
\end{abstract}

\section{Keywords}

Good contractual faith - manifestations - limits

\section{Introducción.}

En mayo de 2016, la Corte Suprema chilena debió resolver el siguiente caso: Una persona compró a la respectiva empresa distribuidora en el país una motocicleta nueva, enduro, por la que pagó en efectivo una suma cercana a los USD 10.000.-. A cambio se le entregó la moto especificada con la respectiva factura de compra. Cuando el comprador concurrió al Registro de Vehículos Motorizados para efectuar la correspondiente inscripción a su nombre, no pudo conseguirlo, porque la motocicleta presentaba problemas de internación al país en el Servicio Nacional de Aduanas. Debido a esto concurrió a la empresa vendedora para obtener una solución al respecto. La cocesionaria realizó innumerables trámites a fin de conseguir la regularización de dichos documentos de internación, pero sin mejores resultados, es decir, la solicitud de inscripción fue igualmente rechazada. 
Debido a la imposibilidad de inscribir la motocicleta a su nombre, el comprador demandó a la empresa, pidiendo la resolución de la compraventa por incumplimiento de la vendedora. Argumentó que el incumplimiento contractual se configura sea que una de las partes no cumpla en absoluto la obligación, sea que únicamente la cumpla en parte, o que cumpla una de las obligaciones y deje de cumplir las otras - arts. 1489 CCCh y 1083 a 1089 CCCNA-. De igual forma, señaló que, conforme de acuerdo al 1546 del Código Civil, los contratos deben ejecutarse de buena fe y por consiguiente obligan no solo a lo que en ellos se expresa sino a todas las cosas que emanan precisamente de la naturaleza de la obligación o que por ley o la costumbre pertenecen en ella. Norma equivalente al artículo 729 del Código Civil y Comercial de la Nación argentino, según el cual deudor y acreedor deben obrar con cuidado, previsión y según las exigencias de la buena fe.

La demandada pidió el rechazo de la acción, manifestando que la moto se entregó materialmente y con su respectiva factura, por lo que, tratándose de un bien mueble, la tradición se verificó legalmente con el traspaso de ella al adquirente - arts. 684 CCCh. y 1892 CCCNA-. Sostuvo, además, que registrar el vehículo motorizado a nombre del comprador no es una obligación que la ley imponga al vendedor, sino que es del propietario del vehículo - art. 34 bis, L. 18.290-. Así las cosas, no se advertía cuál era la obligación incumplida del vendedor que permitiera la resolución. Terminó argumentando que el comprador, en su condición de dueño, podía realizar una gestión judicial con el objeto de requerir que se ordenase al Registro de Vehículos Motorizados la inscripción de la motocicleta a su nombre - art. 43, L. 18.290-.

La sentencia de primera instancia rechazó la demanda porque consideró que el vendedor había cumplido con su obligación legal al hacer entrega del bien al comprador, ya que el actor obtuvo la aprehensión material de la cosa, agotándose las obligaciones que pesaban sobre el demandado, siendo carga de él obtener las inscripciones administrativas que correspondiesen. ${ }^{2}$

La Corte de Apelaciones confirmó lo resuelto, señalando que la imposibilidad de inscribir la motocicleta no constituía un incumplimiento contractual, ya que al actor se le transfirió el dominio según las reglas de la tradición de las cosas muebles, no siendo obstáculo para la eficacia de ella la inscripción, pues esta última solo constituye una presunción de dominio,

2 Primer Juzgado Civil de Chillán, 22 de octubre de 2014, Benitez con Mundaca del Río y Cía., Rol 2351/2014, c. 9. 
y el comprador es quien se encuentra provisto de todas las facultades de este derecho real sobre la motocicleta. ${ }^{3}$

Sin embargo, la Corte Suprema conociendo de un recurso de casación en la forma, anuló la sentencia recurrida, estimando que ella no efectuó una debida ponderación de la prueba y que no expuso suficientemente sus fundamentos.

La Corte Suprema, con base en el artículo 1546 del Código Civil, efectúa un análisis de lo que a su juicio comprende la entrega en la compraventa, asumiendo que, conforme la buena fe, los contratos no solo obligan a lo que en ellos se expresa, sino a todas las cosas que emanan precisamente de la naturaleza de la obligación o que por ley o la costumbre les pertenecen. Afirma que para que la entrega se entienda cumplida, es necesario que se satisfagan aspectos jurídicos y materiales; en tanto ellos no tengan lugar integralmente, la obligación de entregar la especie no está cumplida verdaderamente, de forma que, faltando cualquiera de tales componentes, es posible solicitar la resolución del contrato. La falta de cualquier aspecto que comprenda la obligación de hacer entrega de la especie objeto del contrato de compraventa importa su incumplimiento. La satisfacción de una o más de tales particularidades determina el cumplimiento parcial de la obligación por parte del vendedor. En este caso, si bien la empresa vendedora efectuó la entrega material del vehículo, resulta indudable que dicha entrega "no dejó al comprador en condiciones de usar y obtener los beneficios que tuvo en mente al adquirir la motocicleta, pues, como quedó establecido, al no contar con la inscripción en el Registro de Vehículos Motorizados tampoco posee placas patentes identificatorias y, por tanto, no puede circular por la vía pública" (...) es indudable que "la entrega de una motocicleta que no puede ser inscrita en el Registro de Vehículos Motorizados y que conforme a ello no puede circular por la vía pública, importa un incumplimiento de las obligaciones del vendedor, que incide en un aspecto relevante y principal del contrato considerando la finalidad a la cual está destinado un vehículo motorizado, por lo que, teniendo en vista la intención presunta de los contratantes en el momento inicial, como la actual situación impeditiva para el actor, procede decretar la resolución del contrato de compraventa invocada en la demanda". ${ }^{4}$

Como consecuencia de lo argumentado, se declaró la resolución del contrato y se ordenó a las partes las restituciones correspondientes, sin

3 Corte de Apelaciones de Chillán, 10 de septiembre de 2015, Rol 6/2015, c. 5.

423 de mayo de 2016, Rol 18409/2015, c. 6 a 9. 
indemnización de perjuicios por no haberse solicitado. Dispuso además el pago de las costas a la demandada. ${ }^{5}$

\section{La buena fe objetiva como criterio normativo contractual.}

La citada sentencia de la Corte Suprema es una buena demostración del valor normativo que hoy en día puede llegar a tener la buena fe en el ámbito del cumplimiento de los contratos.

En el moderno entendimiento de la buena fe ella no es solo un principio informador del ordenamiento jurídico en general y de los contratos en particular, sino que se la concibe como un deber de comportamiento típico que la ley impone a los contratantes. ${ }^{6}$ Se trata de una obligación concreta

$5 \quad$ En todo caso la doctrina de la Corte no es nueva, ya que se percibe en varios fallos anteriores. Así, por ejemplo, ya había señalando, en fallo de 30 de julio de 2009, que "la Municipalidad puso término al contrato por incumplimiento en la ejecución de las obras en el plazo estipulado en la oferta (diez meses), argumento que la actora rebate con el planteamiento que dicho plazo no ha empezado a correr, sin embargo, si bien la reclamante hace caudal del principio consagrado como la ley del contrato, debe recordar también el principio de la buena fe consagrado en el artículo 1546 del Código Civil y según el cual los contratos deben ejecutarse de buena fe, y por consiguiente obligan no sólo a lo que en ellos se expresa, sino a todas las cosas que emanan precisamente de la naturaleza de la obligación, o que por la ley o la costumbre pertenecen a ella. Así si se estipuló un plazo para construir a partir de la obtención del permiso de edificación, lo mínimo exigible a un contratante diligente es iniciar los trámites de rigor para la obtención del mencionado permiso, pero ya habían transcurrido un año y cinco meses sin que dicho trámite se iniciara y más aún los actos de la concesionaria sólo demostraban que no había intención de cumplir al comunicar a la municipalidad la inviabilidad económica del proyecto y el aviso de remate de la concesión, de tal suerte que puede hablarse con certeza de incumplimiento del contrato" (Inmobiliaria General S.A. con Municipalidad de Santiago, Rol 667/2008, PuntoLex, c. 10). También había resuelto que "aunque no se haya expresado en la convención, de la misma naturaleza de la relación de obligación creada entre las partes, el principio del cumplimiento de buena fe de los contratos que consagra el artículo 1546 del Código Civil, permite observar una obligación evidente" para las partes, cual era la de efectuar todas las gestiones necesarias para dar cumplimiento al encargo. Habiendo quedado comprobado que el demandado no hizo todo lo que le era exigible para cumplir el encargo profesional, y concretamente en su calidad de corredor de propiedades no informó a su cliente que existía una oferta por un menor precio que satisfacía los intereses de aquella, se configuró "un incumplimiento de obligación a su respecto, que se presume, asimismo, imputable a su culpa" (23 de enero de 2014, Lyon con Thompson, Rol 20/2013, c. 8 de reemplazo, MJJ36948). 6 El que la buena fe tenga un carácter normativo no se opone a que sea también un principio informador del ordenamiento jurídico en general, ya que, como suele ocurrir con los principios generales, ellos requieren de un instrumento concreto de aplicación, que en el caso de la buena fe es el estándar objetivo (cfr. JIMÉNEZ VARGAS-MACHUCA, Roxana: "El principio de la buena fe". En Ameal, Óscar: Obligaciones y contratos en los albores del siglo XXI, Homenaje a Roberto López Cabana. Abeledo-Perrot, Buenos Aires, 2001. p. 764). 
cuya vulneración trae aparejadas las consecuencias propias de cualquier incumplimiento contractual: la posibilidad de solicitar el cumplimiento forzado, la resolución del contrato o la indemnización de perjuicios; $y$, a la inversa, el incumplimiento de la buena fe también implica la posibilidad cierta de que no se dé curso a algunos de estos remedios contractuales cuando la parte que intenta hacerlos valer no actúa conforme la buena fe objetiva que la ley le impone.

Como es sabido, la buena fe tiene aplicación a lo largo de todo el denominado íter contractual. Comienza en las negociaciones preliminares, continúa en la celebración misma del contrato, se extiende luego en la etapa de su ejecución y perdura después de terminado el contrato gobernando el denominado comportamiento poscontractual. Lo que aquí interesa es detenerse en las diversas manifestaciones de la buena fe objetiva en la tercera de estas etapas, esto es, durante la ejecución del contrato; en la llamada buena fe in executivis, manifestaciones que algunos denominan las figuras parcelares de la buena fe, ya que de alguna manera se han configurado como instituciones autónomas dentro del derecho privado, a pesar de que encuentran su fuente principal en la buena fe contractual objetiva. $^{?}$

La buena fe objetiva es conceptualmente diversa de la subjetiva y genera consecuencias también distintas.

La buena fe subjetiva se caracteriza por la creencia o convicción de que se ha actuado conforme a derecho aun cuando así no sea. El derecho suele amparar a quien tiene el convencimiento sicológico de que ha actuado correcta y legalmente, aunque se haya encontrado en un justificado error. Es la buena fe que inspira, por ejemplo, la doctrina del error común, el pago de buena fe a la persona que estaba en posesión del crédito, el matrimonio putativo, el trato favorable al que por ignorancia excusable construye en suelo ajeno, la protección de los terceros que contratan con una sociedad nula, y, probablemente la más conocida, la posesión de buena fe de una cosa ajena, que se traduce en la conciencia o creencia de haber adquirido su dominio por medios legítimos, exentos de fraude y de todo otro vicio - arts. 706 CCCh y 1918 CCCNA-.

$7 \quad$ Cfr. El Derecho de los contratos en Latinoamérica. Bases para unos principios de Derecho de los contratos, Carlos Pizarro Wilson (coordinador). Fondation pour le Droit Continental y Fundación Fernando Fueyo Laneri, Universidad Diego Portales. Santiago, 2012,.pp. 119, 208 y 209. 
En cambio, la buena fe objetivamente considerada es un estándar de comportamiento que la ley exige a todas las partes del contrato, y que impone a los contratantes el deber de comportarse correcta y lealmente en sus relaciones mutuas. ${ }^{8}$ Este concepto llave del derecho Civil implica que los contratantes no pueden tomar ventajas indebidas de su contraparte en los negocios que acuerdan y ejecutan, y genera una regla obligatoria de comportamiento. ${ }^{9}$ A ella se remiten los artículos 1546 del Código Civil chileno y 729 del Código Civil y Comercial de la Nación argentino, cuando prescriben que los contratos deben ejecutarse de buena fe.

"Un estándar es una regla que en lugar de formular una solución rígida, recurre a un parámetro flexible cuyo manejo y concreción, en cada caso, queda entregado al criterio, prudencia y sabiduría del juez de la causa. Se trata, como es sabido, de conceptos susceptibles de asumir un contenido empíricamente variable, pero que, no obstante, tienen una unidad de significado básica e inamovible, la cual debe ser acatada por el sentenciador". ${ }^{10}$

A diferencia de la buena fe subjetiva, que se aprecia in concreto, a través de la investigación y prueba de los hechos que demuestran la convicción personal de la persona que la alega, la buena fe objetiva se determina in abstracto, prescindiendo de las creencias o intenciones psicológicas de los contratantes, a fin de determinar, dentro de lo posible, cuál era la conducta exigible a las partes con base en la ley, la equidad, los usos y al modelo o arquetipo de un hombre razonable. "Se juzga la conducta del sujeto, a fin de determinar si alcanza el nivel exigible, es decir, si se encuentra en concordancia con las reglas admitidas acerca de lo que es bueno y honesto". ${ }^{11}$

$8 \quad$ El Derecho de los contratos en Latinoamérica, ob. cit., pp. 380 y 486 y ORDOQUI CASTILLA, Gustavo: Buena fe contractual. Grupo Editorial Ibáñez, 3ª . ed., Bogotá, 2012. pp. 99 a 101.

9 MACKAAY, Ejan: "Good faith in civil law systems. A legal-economic analysis". En: Revista Chilena de Derecho Privado, 18, julio, 2012. pp. 150, 154, 157 y 177. Explica Boetch que la buena fe alcanza tanto al deudor como al acreedor. El primero "deberá cumplir su obligación buscando satisfacer la legítima expectativa que tuvo el acreedor al momento de contratar, lo que se traduce en que deberá cumplir no solo teniendo a la vista lo expresado en el contrato, sino que buscando satisfacer el espíritu de la prestación" (...) el acreedor deberá "ejercer sus derechos según la confianza depositada por la otra parte, lo cual lo imposibilita de abusar de su crédito en desmedro del deudor, aprovechando circunstancias nocivas que puedan afectar a la parte pasiva de la obligación” (BOETCH GILLET, Cristián: La buena fe contractual. Editorial Jurídica de Chile, Santiago, 2011. p. 112).

10 LÓPEZ SANTA MARÍA, Jorge y ELORRIAGA DE BONIS, Fabián: Los contratos. Parte general. Thomson Reuters, 6a . ed., Santiago, 2017. p. 435.

11 JIMENEZ, ob. cit., p. 767. 
En este sentido, y como anotara del Vecchio, la máxima según la cual los contratos deben ejecutarse de buena fe, representa una notable victoria del espíritu sobre la letra de los contratos. ${ }^{12}$ Esto porque la determinación de qué es o no conforme a la buena fe contractual no puede establecerse mediante pautas genéricas, abstractas y taxativas, sino que se imponen las circunstancias de hecho que rodean al caso, que son las que llevan al juez a decidir en qué tipo de situaciones es posible alejarse del duro texto del contrato.

La buena fe objetiva impone deberes de abstención y de actuación. La denominada buena fe negativa implica que las partes deben abstenerse de desarrollar cualquier comportamiento desleal, lo que envuelve una obligación de no hacer, esto es, de no actuar deslealmente. Pero también existe la buena fe positiva o activa, que supone que cada contratante tiene el deber de cooperación o de colaboración con el otro de cara a conseguir el fin económico del contrato. De esta forma se comprenden en la conducta contractual los deberes de lealtad y cooperación. ${ }^{13}$

\section{La buena fe objetiva: cláusula general de todo contrato.}

Como módulo de comportamiento típico la buena fe objetiva tiene valor normativo, y como tal permite al tribunal determinar para el caso concreto los efectos jurídicos del contrato, ampliando, precisando o restringiendo su texto según las circunstancias que lo envuelven.

Entendida así la buena fe objetiva, significa que ella corresponde a una cláusula general del contrato impuesta por el ordenamiento jurídico, aun en el más absoluto silencio de los contratantes, y es capaz de crear, modificar o extinguir obligaciones jurídicas específicas y concretas. ${ }^{14}$

Por una parte, y en sentido genérico, la buena fe objetiva es una cláusula general en cuanto se configura como una regla de comportamiento que está incorporada en todo contrato, al margen de que las partes lo hayan dicho

12 DEL VECCHIO, Giorgio: Los principios generales del Derecho. $3^{\mathrm{a}}$. ed., Bosch, Barcelona, 1971. p. 121.

13 Cfr. TISSEYRE, Sandrine: Le rôle de la bonne foi en droits des contrats. Essai d'analyse á la lumière du droit anglais et du droit européen. Presses Universitaires d'AixMarseille, Aix-en Provence, 2012. pp. 43 y 44. En sentido semejante MASSE, Claude: Rapport général. La bonne foi, Travaux de l'Association Henri Capitant, Journées lousianeses, Litec, 43, Paris, 1992. p. 223.

14 Cfr. MACKAAY, ob. cit., p. 150 y El Derecho de los contratos en Latinoamérica, ob. cit., pp. 210 y 211 . 
o no en el texto contractual. Se transforma así en una cláusula de orden público, inserta en toda convención, sin que pueda pretenderse que ello se opone a la autonomía de la voluntad y la libertad contractual; pues se trata de una obligación que las partes han deseado o se supone que han querido tanto como aquellas que expresamente estipularon en el contrato, por lo que forma parte del contenido obligacional de éste. ${ }^{15}$

Pero, por otro lado, y en un sentido mucho más preciso, la buena fe es una cláusula contractual general en el sentido que ella no establece una regla específica, fija, determinada y válida para todas las situaciones de hecho que son posibles en una relación contractual. Se trata de un concepto jurídico indeterminado, de una regla abierta en la que se delega al juez el poder de concretizar y definir en cada caso y conforme la situación de hecho qué comportamiento contractual era esperable de las partes. Como anota Gamarra: la cláusula general no dispone de un modelo preconstituido por una normativa definida o analítica, de ahí que se justifiquen las denominaciones de concepto válvula, indeterminado, elástico o discrecional, pues la cláusula general es el instrumento mediante el juez especifica el principio general en sectores más restringidos del ordenamiento, donde éste sea manifiestamente inadecuado para disciplinar relaciones interpersonales, considerando su extrema generalidad. ${ }^{16}$

Por eso que en el derecho moderno se ha desvanecido en alguna medida la noción de contrato estricto o stricti iuris, en el que las obligaciones que imponían tenían los límites precisos e invariables que se indicaron expresamente al otorgarse el contrato. En ellos la obligación estaba definida por las partes en forma explícita, sin margen de variabilidad o flexibilidad. Frente a este tipo de contratos, se yerguen los contratos bonae fidei, en los que sus obligaciones admiten adecuación razonable por la intervención de factores extraños al tenor literal del texto, por lo que todo lo acordado explícitamente debe pasar por el cedazo de la lealtad que se deben los

15 Cfr. BOETCH, ob. cit., pp. 96 ss. y LECLERC, Ginette: "Rapports canadiens”, Travaux..., ob. cit., pp. 269 y 270. Como señala Lorenzetti, "el intérprete puede aplicar esta cláusula general incorporando un elemento objetivo de carácter normativo, ya que es un deber ser" (LORENZETTI, Ricardo Luis: Fundamentos de Derecho privado. Código Civil y Comercial de la Nación Argentina. Thomson-Reuters, Buenos Aires, 2016. p. 275).

16 Cfr. GAMARRA, Jorge: Buena fe contractual. Fundación de Cultura Universitaria, Montevideo, 2011. pp. 12 y 14. 
contratantes. La letra del contrato sumada a la buena fe determinará lo que real y legítimamente es exigible al deudor. ${ }^{17}$

Esta es la idoneidad que tiene la buena fe para generar entre los contratantes los denominados deberes secundarios de conducta, deberes accesorios o deberes anexos de los contratantes, fijando el contenido de las obligaciones contractuales, de tal forma que, frente a lo expresamente acordado en el texto contractual, se agrega aquello que en forma implícita las partes razonablemente entendieron o pudieron entender que era parte del contrato. ${ }^{18}$

En este preciso sentido una ya antigua sentencia dispuso que "los contratos deben ejecutarse de buena fe, sin apego a la letra rigurosa de ellos ni a un derecho estricto. No deben las partes asilarse en la literalidad inflexible para dar menos ni para exigir más, arbitrariamente, al influjo de un interés propio y mezquino; antes bien, ha de dejarse expresar al contrato ampliamente su contenido. Tampoco debe dejarse de atender a factores extraliterales que pudieran fundarse en la naturaleza del pacto, en la costumbre o en la ley". ${ }^{19}$

\section{La buena fe integradora o completiva.}

La integración del contrato es una operación jurídica por la que un contrato se complementa con el recurso a otras fuentes y otros elementos en aquellos casos en que el acuerdo de voluntades pueda resultar incompleto $\mathrm{o}$ insuficiente frente a las previsiones de las partes. ${ }^{20}$ Esta función de la

17 Cfr. FUEYO LANERI, Fernando: Instituciones modernas de Derecho Civil. Ed. Jurídica de Chile, Santiago, 1990. pp. 151 a 153.

18 El Derecho de los contratos en Latinoamérica, ob. cit., pp. 20 y 118 y MENEZESCORDEIRO, Antonio: “Rapport portugais", Travaux..., ob. cit., p. 344.

Desde antiguo las sentencias han afirmado que en la relación contractual junto con los deberes explícitos existen los implícitos. Sobre el punto CORRAL TALCIANI, Hernán: Contratos y daños por incumplimiento, Abeledo-Perrot, Santiago. 2010. pp. 79 ss.

19 CA Pedro Aguirre Cerda, 4 de marzo de 1988, Revista de Derecho y Jurisprudencia, 85, 2, 9. Más recientemente ha señalado la Corte Suprema que "el artículo 1546 del Código Civil consagra una verdadera pauta de integración de los contratos, toda vez que, según ella, estos últimos dictan más allá de su letra todos los componentes que emanan precisamente de la naturaleza de la obligación o que por la ley o la costumbre pertenecen a ella" (Municipalidad de Puerto Montt con Constructora Isla del Rey Ltda., 7 de noviembre de 2016, Rol 52838/2016, c. 6).

20 Sobre el particular DOMÍNGUEZ HIDALGO, Carmen,:“Aspectos de la integración del contrato". En: Estudios de Derecho Civil VI, Jornadas Nacionales de Derecho Civil, Olmué, 2010. AbeledoPerrot-LegalPublishing, Santiago, 2011. pp. 251 ss., LYON PUELMA, Alberto: 
buena fe, descubierta por Demogue y extendida por De Page, impone que frente a la insuficiencia del marco contractual el tribunal o intérprete pueda cumplimentar el marco normativo, y los derechos y obligaciones que el contrato impone a las partes. ${ }^{21}$ Por este procedimiento jurídico acontece que el negocio jurídico producirá consecuencias no establecidas explícitamente en el texto contractual, pero que son posibles en atención al espíritu del contrato y la intención de los contratantes, a fin que el contrato cumpla con su finalidad económica y satisfaga la utilidad que han tenido a la vista las partes al celebrarlo. ${ }^{22}$ Impone el deber de realizar lo necesario para lograr el resultado útil de la prestación. ${ }^{23}$ Se genera por esta vía una multiplicación o derivación de derechos y obligaciones contractuales no previstos inicialmente por los contratantes, siendo el juez quien supla las insuficiencias del contrato por medio de su integración.

A veces la ley expresamente dispone la integración y la forma en que ella debe hacerse. Así sucede, por ejemplo, en el artículo 964 del Código Civil y Comercial de la Nación argentino, que específicamente señala que "el contenido del contrato se integra con: a. las normas indisponibles, que se aplican en sustitución de las cláusulas incompatibles con ellas; b. las normas supletorias; c. los usos y prácticas del lugar de celebración, en cuanto sean aplicables porque hayan sido declarados obligatorios por las partes o porque sean ampliamente conocidos y regularmente observados en el ámbito en que se celebra el contrato, excepto que su aplicación sea irrazonable". ${ }^{24}$

"Integración e interpretación del contrato". En: Estudios jurídicos en homenaje al profesor Pablo Rodríguez Grez. Ediciones Universidad del Desarrollo, Santiago, 2009, en especial, pp. 195 ss. y TAPIA MALIS, Liat: "La buena fe como mecanismo de integración eficiente". En: Estudios de Derecho Civil X, Jornadas Nacionales de Derecho Civil, Valparaíso, 2014. Thomson Reuters, Santiago, 2015. pp. 537 ss.

21 PÉRILLEUX, Jacques: “Rapport belge”, Travaux..., ob. cit., p. 244.

22 BOETCH, ob. cit., pp. 115 a 119 y GAMARRA, ob. cit., p. 140.

23 ORDOQUI, ob. cit., p. 372.

24 La doctrina suele diferenciar la autointegración de la heterointegración. La primera, que se llama interpretación integradora, es la que tiene lugar procurando resolver el conflicto contractual únicamente al alero del texto del contrato, rellenando sus posibles vacíos sólo con el espíritu y sentido de las cláusulas que los contratantes expresaron, sin recurrir a elementos extracontractuales o externos a la convención. La idea es determinar, conforme al texto del negocio, lo que habrían dispuesto los contratantes en el evento de haberse representado el problema generado en la ejecución del contrato. La integración se hace entonces con la "lógica del contrato", puesto que a partir de sus cláusulas expresas se deducen o infieren cláusulas nuevas que pasan a integrarlo. La heterointegración, en cambio, es la que se hace recurriendo elementos que no están en el clausulado de la convención, por lo que las nuevas cláusulas a fin de cuentas derivan de normas externas a ellas. El juez podrá 
En otras ocasiones la integración del contrato se dispone por la ley de manera menos categórica, al derivar y vincular la integración contractual a la buena fe con que deben actuar las partes en la ejecución del contrato. Así ocurre con el artículo 1546 del Código Civil chileno, cuando prescribe que los contratos deben ejecutarse de buena fe, y como consecuencia no sólo obligan a lo que en ellos se expresa, sino que también a todo lo que resulta conforme a la naturaleza de la obligación, a la costumbre o a la ley.

En estos casos existe la posibilidad que el contrato resulte integrado gracias a la regla de la buena fe, hipótesis en el que se configura la llamada buena fe completiva o integradora. Ella pasa así de estática a dinámica, pues no bastará la sola lectura literal del contrato, sino que junto con ello deberá recurrirse a la intención de los contratantes cuando se requiera para que, de este modo, impedir que la ejecución exegética de la obligación viole el contrato mismo, pues la buena fe completiva hace primar espíritu del contrato sobre su formalismo. ${ }^{25}$

De la buena fe completiva o integradora se derivan aquellos deberes contractuales de comportamiento que no estaban explícitamente previstos en el texto del contrato pero que emanan de la finalidad buscada al contratar. Son, como se ha dicho, los denominados deberes implícitos en las prestaciones contratadas; los deberes colaterales de conducta ${ }^{26}$ los denominados implied terms del Derecho inglés, o las prestaciones virtualmente comprendidas en las obligaciones explícitas que las partes asumieron. ${ }^{27}$ Todos estos deberes, a fin de cuentas, descienden de la buena

recurrir para ello a las normas de rango constitucional, a los principios generales del derecho, a la buena fe o a los usos y costumbres.

Con todo, respecto de la autointegración, la crítica se basa en que si las partes se hubieren representado el problema es probable que le hubieran dado una solución en el contrato en una forma favorable a sus intereses, resultando muy complejo y difícil establecer una hipotética voluntad común sobre el vacío. Además, ello supondría que en él están todos los elementos con los que el juez puede llenar el vacío, lo que acercaría la operación a una interpretación contractual y la alejaría de una integración del contrato. La autointegración recurriría a voluntades presuntas, conjeturales o hipotéticas, y constituiría una "ciencia ficción sobre lo que las partes hubieren podido querer y no quisieron, lo que entendemos inaceptable" (ORDOQUI, ob. cit., p. 219).

25 TISSEYRE, ob. cit., pp. 248, 256 y 257.

26 Cfr. BERNAL FANDIÑO, Mariana: "La naturaleza jurídica de la responsabilidad civil derivada de los deberes colaterales de conducta”. En: Vniversitas, Bogotá, 126, 2013. pp. 42 y 43. 27 Cfr. El Derecho de los contratos en Latinoamérica, ob. cit., p. 381. Es la nomenclatura recogida en los Principios de Derecho Europeo de los Contratos. Según su artículo 6:102, referido a términos implícitos del contrato "junto a cláusulas expresas, un contrato puede contener cláusulas implícitas que derivan de: a) La intención de las partes. b) La naturaleza y el objeto del contrato. c) Y la buena fe". 
fe y no del texto del contrato. ${ }^{28}$ "Se sustentan implícitamente en la buena $\mathrm{fe}, \mathrm{y}$ en lo que verosímilmente las partes entendieron o pudieron entender, obrando con cuidado y previsión". ${ }^{29}$ A este respecto es esencial considerar la fisonomía del contrato y específicamente las relaciones que nacen entre los contratantes, ya que ciertos contratos, en razón de su naturaleza, materialmente crean entre las partes relaciones de confianza, lo que resulta muy relevante para establecer las obligaciones complementarias que los asisten. $^{30}$

\section{Las principales manifestaciones de la buena fe en la ejecución de los contratos o criterios de decisión para situaciones contractuales difusas.}

¿Qué trascendencia práctica y concreta tiene en la aplicación de un contrato toda la construcción teórica sobre la buena fe contractual? Mucha y determinante. La buena fe que debe presidir la ejecución del contrato se manifiesta en una serie de situaciones jurídicas en las que la aplicación del puro texto contractual aparece como una solución insatisfactoria o difusa en consideración a realidad de las cosas y las circunstancias de hecho que rodearon la ejecución de la convención. Estas manifestaciones operan o pueden operar como criterios jurídicos relevantes para tomar decisiones que tienen el mérito de resolver el conflicto contractual no solo en justicia, sino que también con estricto apego a la juricidad, pues no se trata de enunciados puramente equitativos sin base legal alguna, sino que son una expresión legal y jurídica del principio general que reza que los contratos deben ser ejecutados de buena fe. De modo que, dentro de los límites que se indican en el punto VI, la sentencia que se apoya en ellos para decidir la cuestión controvertida no hace un puro ejercicio justicia a la manera que pueda ser ella entendida por el tribunal, sino que aplica el valor propiamente normativo de la buena fe en el cumplimiento del contrato.

Es complejo intentar la confección de un catálogo de las manifestaciones concretas que se derivan de la buena fe objetiva contractual, ya que siempre se corre el riesgo de que alguna pueda ser preterida. A pesar de ello, y con un puro propósito enunciativo y no analítico, ya que el estudio particular superaría con creces el objetivo y espacio de este trabajo, puede señalarse

28 ORDOQUI, ob. cit., p. 223; TISSEYRE, ob. cit., pp. 290 a 293; MASSE, ob. cit., p. 225 y PÉRILLEUX, ob. cit., p. 244.

29 STIGLITZ, Rubén y STIGLITZ, Gabriel: Fallos y doctrina argentina, http:// jurisprudencia paratodos.blogspot.cl, 13 de abril de 2013, punto II.

30 TISSEYRE, ob. cit., p. 302. 
que existe cierto consenso doctrinario respecto de que, en el ámbito de la ejecución de un contrato, son manifestaciones de la buena fe objetiva a la que están obligadas las partes, las siguientes:

1. El deber de colaboración contractual. ${ }^{31}$ Los contratos, unos más que otros, suponen la necesaria colaboración o cooperación del acreedor para que el deudor pueda cumplir con sus obligaciones debidamente. En ellos la prestación del deudor deviene en dificultosa o francamente imposible si el acreedor no cumple con hacer todo lo que sea indispensable para que la prestación que se le debe pueda ser cumplida por la contraparte en tiempo y forma. ${ }^{32}$ Entendido así este deber es el que asiste a los contratantes de

31 Sobre el particular PRADO LÓPEZ, Pamela: La colaboración del acreedor en los contratos civiles. Thomson Reuters, Santiago, 2015.

32 La Corte Suprema chilena ha extendido el deber de colaboración incluso a las relaciones laborales. En fallo de fecha 4 de diciembre de 2008, señaló que "como lo ha declarado esta Corte en otras oportunidades, el contrato de trabajo se encuentra también marcado por un contenido ético, es decir, por el imperio de ciertos principios que las partes deben respetar, entre ellos, el deber de fidelidad y lealtad a que ambas se encuentran obligadas, atendidas, entre otras, las circunstancias de alta competitividad en el que se desarrollan en el mundo moderno las actividades empresariales". "En efecto, el mayor o menor éxito de una empresa radica en la calidad y variedad de los productos que ofrezca a los consumidores de los mismos, características que, a su vez, dependen de un acertado proceso de producción en el que, sin duda, los trabajadores juegan un rol principal". "Por lo mismo, las relaciones laborales han de desenvolverse en un clima de confianza, el que se genera en la medida que las partes cumplan con sus obligaciones en la forma estipulada, fundamentalmente, de buena fe, principio del cual se encuentra imbuido toda nuestra legislación y consagrado, especialmente en materia contractual, en el artículo 1546 del Código Civil". "De esta manera, los mencionados deberes de solidaridad y colaboración, integrantes de la carga ética aludida, son claras directrices del comportamiento de los contratantes durante la vigencia de su vinculación, sujetándolos a varios deberes que si bien no han sido explicitados en el texto del contrato pertinente o consensuados expresamente, emanan de la naturaleza de la relación laboral, por ejemplo, que ninguna de las partes actuará en perjuicio o detrimento de la otra". "Que como consecuencia de lo señalado, ante ciertas conductas del trabajador, graves y debidamente comprobadas, el legislador autoriza al empleador a poner término a la vinculación, sancionando a aquél con la pérdida de las indemnizaciones que, en ausencia de las primeras, le habrían correspondido, como ocurre con la invocada por la demandada para justificar el cese de los servicios de los demandantes, pues ella implica que la convención no se está realizando de buena fe o el contratante respectivo no está siendo diligente al desarrollar las funciones para las que se le contrató". Más recientemente la Corte de Apelaciones de Santiago, señaló que "la conducta reprochada al demandado es no haber adoptado el más mínimo resguardo que puede tomar un trabajador medianamente diligente frente a la evidencia de que, en un ámbito que se halla dentro de sus ordinarias funciones, se ha cometido un cuantioso delito (que no otra cosa es la adulteración de dos vales vista por más de veintisiete millones de pesos), omisión que ha redundado en una pérdida de más de cincuenta y ocho millones de pesos. Y para que el demandado cumpliera sus deberes contractuales no se requería instructivo alguno, pues en sí mismos estos hechos escapaban del normal transcurso de las actividades de cualquiera 
ejecutar cuanto sea necesario para que el contrato cumpla con su función económica, esto es, la utilidad perseguida por las partes. Es el aspecto solidario de la buena fe, que entiende al contrato bilateral y oneroso no solo como una fuente generadora de derechos y obligaciones, sino que como un instrumento de encuentro de voluntades y esfuerzos comunes encaminados al recíproco beneficio. ${ }^{33}$ De ahí que se diga que la buena fe en la ejecución de un contrato implica el deber de cada una de las partes de realizar el interés contractual de la otra. ${ }^{34}$ También por eso el artículo 354.2 del Código Civil de Polonia, por ejemplo, señala con claridad que el acreedor debe contribuir a la ejecución de la obligación. Si el acreedor no colabora o no coopera se excluye la responsabilidad contractual del deudor por su posible incumplimiento, y eventualmente puede configurarse la del propio acreedor. ${ }^{35}$

empresa y necesariamente correspondía que fueran comunicados a la empresa, esto es en definitiva el reproche se funda en el incumplimiento de buena fe de las obligaciones que imponía el vínculo laboral, con diligencia y esmero, colaborando lealmente con el patrón, cuestión de suyo evidente que no necesita plasmarse en ninguna norma escrita, sin perjuicio de -por lo demás- tener su fuente positiva en el artículo 1546 del Código Civil, disposición que es aplicable a toda clase de contratos, incluido aquel celebrado por las partes de autos" (1 de septiembre de 2016, Sociedad Comercializadora y de Servicios Macal Limitada con Barra, Rol 1189/2016, c. 10, MJJ46413). (Flores y otro con VTR Globalcom, Rol 6072/2008, PuntoLex, c. 6 y 7). Sobre la ejecución de buena fe del contrato individual de trabajo, cabe remitirse al fallo de casación de la Corte Suprema de 17 de marzo de 2003, Sternsdorf con Manaplast S.A., comentado por GAMONAL CONTRERAS, Sergio: I Revista de Derecho, Universidad Adolfo Ibáñez, 2004).

33 GAMARRA, ob. cit., pp. 21, 22 y 33.

34 SAAVEDRA, Francisco: "El principio general de la buena fe". En: Instituciones modernas de Derecho Civil, Homenaje al profesor Fernando Fueyo Leneri. Ed. Jurídica Conosur, Santiago, 1996. p. 369.

35 Señala Ducci que "tanto las disposiciones de aplicación general como particulares de determinados actos y contratos demuestran fehacientemente que el criterio del Código es excusar al deudor cuando su incumplimiento proviene total o parcialmente de una causa extraña, incluida la culpa del propio acreedor". Siguiendo la doctrina gala afirma que el autor que "sería absolutamente nefasto, tanto desde el punto de vista de la conciencia social como desde el punto de vista de la dignidad humana, que el culpable pudiese hacer gravitar sobre la culpa de otro el daño que se ha causado, olvidando su propia responsabilidad" (DUCCI CLARO, Carlos: "La culpa del acreedor en la responsabilidad contractual". En: Revista de Derecho y Jurisprudencia, 81. pp. 3 y 5). Rodríguez denomina a esta eximente del deudor "eliminación del factor de imputación por culpa del acreedor" (Rodríguez Grez, Pablo, Responsabilidad contractual, Santiago, Editorial Jurídica de Chile, 2003, pp. 199 y 203). En esta misma línea se pregunta Pizarro “¿cómo permitir que alguien pueda reclamar la indemnización de un daño que él mismo causó? Atender a esta pretensión iría en contra de las bases de la responsabilidad civil". La ausencia de la necesaria actuación del acreedor es un hecho "imprevisto para el deudor e irresistible, lo que redunda en la exoneración de 
2. La improcedencia de la resolución contractual por incumplimientos menores. A pesar de que la mayor parte de los códigos decimonónicos no establecieron precisiones en este punto, bastando en teoría cualquier incumplimiento para admitir la resolución de un contrato, parece haberse impuesto muy fuertemente tanto en la doctrina como en la jurisprudencia contemporáneas la concepción de que la resolución que implica la muerte del contrato debe solicitarse de buena fe, ${ }^{36} \mathrm{y}$, por tanto, no cualquier incumplimiento del deudor tiene la potencialidad de generar la resolución de un contrato, restringiéndose la procedencia de la resolución para aplicarla en los denominados incumplimientos importantes graves, esenciales o resolutorios..$^{37}$ Esta idea encuentra su principal sustrato en el deber de buena fe que le impone a las partes el contrato, resultando contrario a este módulo de comportamiento que una de las partes pueda pretender que un contrato deba ser dejado sin efecto por el incumplimiento de obligaciones muy menores o que no dicen relación con el verdadero y determinante interés del acreedor en el contrato.

3. La improcedencia de la exceptio non rite adimpleti contractus. Esta excepción es la que se configura cuando el cumplimiento del contrato no ha sido exacto, ritual o conforme la más rigurosa letra del contrato. A través de ella el demandado que la opone alega que el actor no cumplió exacta, completa y rigurosamente sus obligaciones. Se invoca por el demandado que su propio incumplimiento está justificado, habida cuenta que el actor

responsabilidad excluyendo toda indemnización de perjuicios. En este ámbito, a propósito de la responsabilidad, tanto el hecho del acreedor como la mora creditoris inciden en la exclusión de indemnización". Por ello, "la mora creditoris o mora del acreedor", es un "obstáculo para la ejecución que impide al deudor el cumplimiento". "Si un daño que se demanda ha sido fruto del actuar del propio acreedor no procede indemnización alguna", ya que "si el daño tiene su origen en forma exclusiva en la conducta del acreedor, no cabe responsabilidad por ausencia de causalidad" (PIZARRO WILSON, Carlos: "El hecho del acreedor en la responsabilidad contractual", Estudios de Derecho Civil X, Jornadas Nacionales de Derecho Civil, Valparaíso, 2014. Thomson Reuters, Santiago, 2015. pp. 624, 630 y 631). Fueyo se refiere a ella como "falta de cooperación indispensable del acreedor" (FUEYO LANERI, Fernando: Cumplimiento e incumplimiento de las obligaciones, Santiago, Editorial Jurídica de Chile, 2004. p. 453). Ramos la califica como eximente de responsabilidad por "hecho o culpa del acreedor", y explica que a partir de lo señalado en los artículos 1548, 1680 y 1827 del Código Civil, ella configura una especial causal de exoneración de responsabilidad civil del deudor (RAMOS PAZOS, René: De las obligaciones. Ed. Jurídica de Chile, Santiago, 1999. pp. 257 y 267).

36 Cfr. ORDOQUI, ob. cit., p. 440.

$37 \quad$ Esta es una idea muy arraigada en la generalidad de la doctrina y jurisprudencia latinoamericana actual (cfr. El Derecho de los contratos en Latinoamérica, ob. cit., pp. 82, $119,182,270,271,464,535,624$ y 625$)$. 
no cumplió literalmente con lo que decía el contrato, a pesar de que lo que ese incumplimiento ha sido en verdad insignificante o intrascendente. La excepción se transforma así en una simple excusa formal en favor del deudor. Tal comportamiento del demandado contraviene la buena fe contractual, ya que un incumplimiento de menor jerarquía por parte del acreedor, no legitima un incumplimiento esencial por parte del deudor.

4. El pago de buena fe. Es sabido que la identidad e integridad del pago (o la paga) implican que el cumplimiento de la obligación debe hacerse conforme lo establece el tenor del contrato, debiendo ser además completo y no fraccionado - arts. 1569 y 1591 CCCh y arts. 868 y 869 CCCNA-. A ello debe agregarse que el pago del solvens debe ser hecho de buena al accipiens. El acreedor está en posición jurídica de exigir que la prestación se ajuste a lo que la buena fe dispone, y que no quede "por debajo de lo que la buena fe reclama y, por otro lado, debe conformarse el acreedor -y no exigir más-cuando el deudor realice lo que la buena fe le exige. Por otra parte, el deudor puede exigir que no se le imponga más carga o esfuerzo que aquello que se conforma al cumplimiento de buena fe" (...) "los afectados por este principio son tanto el acreedor, limitado así en su pretensión, como el deudor, exigido para superarse en ciertos casos como también para limitarse en su carga o esfuerzo". Así, por ejemplo, no estando precisado el momento exacto del pago, no parece acorde a la buena fe que este se haga en un día festivo, de noche o en un momento en el que el acreedor conocidamente no pueda comparecer a recibirlo. De la misma manera, la buena fe sugiere que el pago de una deuda de dinero se haga con aplicación de una correcta y prudente indexación monetaria, a fin de no causar perjuicio a cualquiera de las partes. $\mathrm{O}$ incluso, a quien aprovechan los frutos de la cosa que recibe como pago, debiera soportar las cargas asociadas a ella. ${ }^{38}$

5. La admisión de la doctrina de la imprevisión contractual. Una muy fuerte corriente doctrinaria y judicial que ya hace bastante se ha traducido en normas legales expresas, entiende la posibilidad de revisar los términos contractuales en aquellos casos que circunstancias extraordinarias o imprevisibles hagan que la prestación de una de las partes se transforme en excesivamente onerosa o exorbitante, encuentra su fundamento

$38 \quad$ Cfr. FUEYO LANERI, Fernando: "La ejecución de buena fe de los contratos como uno de los requisitos del pago". En: Revista de Derecho y Jurisprudencia, 55, 1958. pp. 93 ss. 
precisamente en el deber de buena fe contractual. ${ }^{39}$ La fuerza obligatoria de los contratos se proyecta a lo previsto por las partes en él, pero no se extiende a lo imprevisto, pues la probidad del contrato impone que el acreedor no pueda pretender más en el ejercicio de su crédito. ${ }^{40}$ Es la denominada función adaptativa de buena fe, aplicable en aquellos casos en que el contexto económico en que se celebró el contrato y que precedió a las negociaciones cambia de forma importante haciendo que la ejecución de lo acordado resulte excesivamente onerosa.$^{41}$ Muchos Códigos americanos han recogido esta doctrina. Así sucede, por ejemplo, con los Códigos de Argentina (art. 1091), Perú (arts. 1440 y ss.), Brasil (arts. 478 a 480), Paraguay (art. 672) y Bolivia (arts. 381 a 383). El Código Civil francés, con seguridad el más influente del mundo, ha terminado por sucumbir a esta esta institución. Después de la reforma introducida por la Ordenanza 2016131 de 2016, su artículo 1195 señala que "si un cambio en las circunstancias imprevisibles al momento de celebración del contrato desemboca en una ejecución excesivamente onerosa para una de las partes, que no ha aceptado asumir tal riesgo, ella pueda demandar una renegociación del contrato a su contraparte. Ella debe continuar cumpliendo sus obligaciones durante la renegociación". "En caso de fracaso de la renegociación, las partes pueden convenir la resolución del contrato en las condiciones que ellas determinen, o demandar de común acuerdo al juez que proceda a su adaptación. A falta de acuerdo en un plazo razonable, el juez puede, por la demanda de una de las partes, revisar el contrato o ponerle fin, en la fecha y las condiciones que él fije". ${ }^{42}$

6. El acogimiento de la doctrina del estoppel. La buena fe impide que una parte pueda, en perjuicio de la otra, contradecir sus claras conductas pasadas, pues existe el deber contractual de no contravenir los actos propios (venire contra factum proprium non valet). ${ }^{43}$ Explica Wieacker que esta "máxima expresa de forma tan inmediata la esencia de la obligación de comportarse de acuerdo con la buena fe que a partir de ella se alumbra la

$39 \quad$ Cfr. MOMBERG URIBE, Rodrigo: "La revisión del contrato por las partes: El deber de renegociación como efecto de la excesiva onerosidad sobreviniente". En: Revista Chilena de Derecho, 2010, 37, 1. pp. 43 ss. y BOETCH, ob. cit., pp. 123 a 128.

$40 \quad$ Cfr. ORDOQUI, ob. cit., pp. 461 y 462.

41 Cfr. MASSE, Rapport général, Travaux..., ob. cit., p. 226.

42 La norma ya ha suscitado algunas críticas. Sobre el particular MARTIN, Simon: A propos de l'article 1195 du Code Civil tel que rédigé par l'ordonnance du 10 février 2016, disponible en www.village-justice.com/articles/propos-article-1195-code-civil-tel, 21536.html. 43

Derecho de los contratos en Latinoamérica, ob. cit., p. 119. 
totalidad del principio". ${ }^{44} \mathrm{Si}$ una de las partes desarrolla un determinado comportamiento contractual, genera en la otra la confianza que ese es el correcto entendimiento que ella le da al contrato, resultando contrario a la buena fe pretender que las conductas pasadas carecen de valor a los efectos de la realidad actual en la ejecución contractual. ${ }^{45}$ La cuestión se

$44 \quad$ WIEACKER, Franz: El principio general de la buena fe, Civitas, traducción de José Carro, reimpresión, Madrid, 1986. pp. 61 y ss. Véase también GAMARRA, ob. cit., pp. 25 y ss. 45 La jurisprudencia ha aplicado recurrentemente esta manifestación de la buena fe. Sobre este punto ha sentenciado la Corte de Apelaciones de Santiago, en fallo de 13 de mayo de 2008, que el principio de los actos propios, venire contra propium factum nulli conceditur, "constituye un principio general del derecho que, evidentemente, informa todo nuestro ordenamiento jurídico. En efecto, como se ha dicho por esta Corte y por la Excma. Corte Suprema de Justicia, tal doctrina se traduce en que se debe mantener en el derecho una conducta leal y honesta y, desde luego, es la inspiración de la regla por la cual nadie puede aprovecharse de su propio dolo o fraude, encontrando en materia contractual su base legal en el referido artículo 1546 del Código Civil. Son requisitos de procedencia de esta teoría: a) una conducta anterior, que revela una determinada posición jurídica de parte de la persona a quien se le trata de aplicar este principio; b) una conducta posterior por parte del mismo sujeto, contradictoria con la anterior; y c) que el derecho o pretensión que hace valer la persona a quien incide el actor perjudique a la contraparte jurídica (Rol 5958/2006, PuntoLex, c. 5). La Corte Suprema, en fallo de 19 de abril de 2011, ha señalado que para desestimar la nulidad impetrada "no puede dejar de anotarse que a nadie le es lícito hacer valer un derecho civil o procesal en contradicción con su anterior conducta jurídica. Esta doctrina, conocida como de los actos propios, ha sido recogida en diversas disposiciones de nuestro Código Civil, como los artículos 1683, 1481, 1546 y, en su forma de expresión conocida como buena fe, informa en carácter de principio general todo el referido cuerpo de leyes. Ella permite al sentenciador ponderar la actitud lógica del actor o de su contraparte, que puede incidir en la acción misma o en un simple incidente (Raúl Díez Duarte, $E l$ contrato: Estructura civil y procesal, Editorial Jurídica Conosur, 1994, pag. 365 y siguientes). Así, se impide jurídicamente el que una persona afirme o niegue la existencia de un hecho determinado, en virtud de haber antes ejecutado un acto, hecho una afirmación o formulado una negativa en el sentido precisamente opuesto, pues de acuerdo a este principio, nadie puede contradecir lo dicho o hecho por él mismo, con perjuicio de un tercero. De esta manera, los actos propios encuadran el derecho de los litigantes, de forma que no puedan pretender que cuando han reclamado o negado la aplicación de una determinada regla en beneficio propio, puedan aprovechar instrumentalmente la calidad ya negada precedentemente, con perjuicio de los derechos de su contraparte" (Cremaschi con Esso Chile Petrolera Ltda., Rol 8332/2009, c. 7). La misma Corte, esta vez en fallo de 14 de noviembre de 2016, ha señalado que "si bien nuestro sistema normativo no establece una regulación específica en relación con aquélla, lo cierto es que la teoría en comento, vertida inicialmente en la máxima venire contra factum proprium non valet, ha adquirido amplia acogida durante los últimos tiempos en la doctrina de los autores y en la jurisprudencia, donde se la reconoce como un criterio orientador derivado del principio general de la buena fe concebida ésta en su faz objetiva a la que se refiere el artículo 1546 inciso $3^{\circ}$ del Código Civil cuando prescribe que los contratos deben ejecutarse de buena fe y que, por consiguiente, obligan no sólo a lo que en ellos se expresa sino a todas las cosas que emanan precisamente de la naturaleza de la obligación o que por la ley o costumbre pertenecen a ella" (Intequip Mining Sales And Services Ltd con Altamirano, Rol 45787/2016, c. 10). 
vincula muy estrechamente a la doctrina de la apariencia, conforme la cual la parte contractual que con sus actuaciones reiteradas genera en la otra parte ciertas convicciones acerca de la realidad de las cosas, debe hacerse responsable por ello, a pesar de que la apariencia no corresponda exactamente con la realidad material o jurídica. ${ }^{46} \mathrm{La}$ aplicación de este principio se hace especialmente interesante en la denominada tolerancia del acreedor, a veces por largo tiempo, a incumplimientos inexactos y reiterados del deudor en la ejecución del contrato, casos en los que logra la convicción que su comportamiento es considerado por el acreedor como ajustado al contrato y que no le merece reproche. En principio, podría pensarse que la tolerancia del acreedor no implica una renuncia a reclamar de la inexactitud del incumplimiento en un momento posterior; pero, dependiendo de los casos y las circunstancias de hecho, la buena fe bien puede conducir a que después de toda la larga ejecución del contrato el acreedor no pueda reclamar con éxito que una antigua obligación contractual no fue completamente ejecutada conforme con la literalidad del contrato. ${ }^{47}$ Cuando una de las partes ha ejecutado el contrato de una manera que no es exactamente la prevista inicialmente, a vista y paciencia de la otra, o con su conocimiento, aprobación o colaboración, no puede esta última, sin

$46 \quad$ En aplicación de esta doctrina la Corte Suprema resolvió, el 23 de noviembre de 2009, que "como ha señalado anteriormente esta Corte, en las manifestaciones de la vida jurídica, al igual que en otros dominios, no siempre la realidad concuerda con las apariencias. Frente a la dualidad de apariencia y realidad surge el deseo de proteger a los terceros". "Las apariencias merecen fe, por cuanto resulta difícil precisar si ellas corresponden o no a la realidad. Es así que cuando el interés de los terceros de buena fe lo hace necesario, los jueces no deben considerar totalmente ineficaz un acto ejecutado por quien se ha comportado como titular verdadero del derecho y lo hace oponible al titular real". "En consecuencia, la apariencia de personalidad, de titularidad o de legitimación equivale a la personalidad, titularidad o legitimación mismas. Existen, por consiguiente, situaciones por las cuales quienes han confiado razonablemente en una manifestación jurídica dada ante una apariencia determinada, y se han comportado de acuerdo con tal manifestación o apariencia, tienen derecho a contar con ellas, aunque no correspondan a la realidad, especialmente cuando se la ha permitido de hecho o se ha omitido reacciones por la entidad en tales condiciones representada" (Rol 6673/2009, PuntoLex, c. 4).

$47 \quad$ La cuestión más discutida en este tipo de situaciones es la precisar si, más allá de la buena fe objetiva, existe un el fundamento jurídico preciso que permita concluir que el cumplimiento del deudor inexacto y reclamado no da lugar a reproches del acreedor. Para algunos se trataría de una renuncia del acreedor a su derechos; para otros se estaría ante una suerte de modificación tácita del contrato y para un tercer grupo esta sería una cuestión de interpretación contractual, en donde para determinar si es atendible el reclamo del acreedor debe tomarse en cuenta la aplicación práctica que las partes han hecho del contrato, y así establecer si lo ejecutado y no reclamado se ajusta a la intención y finalidad económica del negocio (cfr. GAMARRA, ob. cit., pp. 61ss.). 
infringir la buena fe contractual, afirmar después que el cumplimiento no se ajustó a la literalidad de lo estipulado, ya que a nadie le es lícito contravenir sus propias actuaciones. Así, por ejemplo, si el mandante de una obra la recibe del artífice a través de un procedimiento formal pero distinto del inicialmente previsto en el contrato, no puede después pretender que la obra no le ha sido entregada.

7. El deber de mitigar los daños. ${ }^{48}$ El principio en este punto es que el deudor no responderá de los perjuicios que el acreedor pudo evitar con una actuación medianamente diligente y que no impidió que ocurrieran. Aun cuando algunos entienden que la irresponsabilidad del deudor por estos daños se basa en la falta de relación causal que ellos tienen con el incumplimiento, ${ }^{49}$ lo que parece meridianamente claro es que no resulta armónico con la buena fe contractual que el acreedor permita que su daño se siga expandiendo sin hacer nada por evitarlo, aumentando así la responsabilidad del deudor. ${ }^{50}$

8. El deber de no competir. La buena fe contractual impone el imperativo ético que le asiste a cada una de las partes del contrato de no realizar actividades paralelas a la relación contractual que causen perjuicio a la contraparte. Este deber se configura más nítidamente en los contratos laborales y dentro de las sociedades civiles y comerciales. El trabajador debe evitar realizar negocios que puedan perjudicar al su empleador, ${ }^{51}$

$48 \quad$ Véase DOMÍNGUEZ ÁGUILA, Ramón: "Notas sobre el deber de indemnizar el daño". En: Revista Chilena de Derecho Privado, 5. pp. 73 ss.; FUENTES GUIÑEZ, Rodrigo: "El deber de evitar o mitigar el daño". En: Revista de Derecho, Universidad de Concepción, 217-218, 2005. pp. 225 ss.; LÓPEZ SANTA MARÍA, Jorge: "Sobre la obligación de minimizar los daños en el derecho chileno y comparado". En: Los contratos en el Derecho Privado. Editorial Legis,Bogotá, 2005. pp. 325 ss.; VIDAL OLIVARES, Álvaro. "La carga de mitigar las pérdidas del acreedor y su incidencia en el sistema de remedios por incumplimiento". En: Estudios de Derecho Civil III, Jornadas Nacionales de Derecho Civil, Valparaíso, 2007. LegalPublishing, Santiago, 2008. pp. 429 ss.; PIZARRO WILSON, Carlos: "Contra el fatalismo del perjuicio: A propósito del deber de mitigar el daño". En: Revista de Derecho, Universidad Católica de Valparaíso, 41, 2013. pp. 69 ss. y VIDAL OLIVARES, Álvaro: "La carga de mitigar las pérdidas del acreedor y su incidencia en el sistema de remedios por incumplimiento". En: Estudios de Derecho Civil III. Santiago, LegalPublishing, 2008. pp. 429 ss.

49 Los perjuicios en este caso no derivarían del incumplimiento del deudor, sino que de la falta de diligencia del acreedor (cfr. en este sentido TISSEYRE, ob. cit., pp. 120 y 121). 50 Cfr. Derecho de los contratos en Latinoamérica, ob. cit., pp. 200, 201, 370, 472, 544 y 635 .

51 En otro orden de materias, la Corte de Apelaciones de Santiago, en fallo de 11 de enero de 2005, aplicando este principio, resolvió que, si el trabajador cumplía funciones de gerente de la división de electrónicos de consumo, y desarrolló actuaciones de índole 
así como el socio o administrador de una sociedad debe abstenerse de realizar emprendimientos que comprendan el mismo giro social que explota su compañía. En este sentido, el artículo $404.4^{\circ}$ del Código de Comercio chileno, prohíbe a los socios explotar por cuenta propia el ramo de industria en que opere la sociedad, y hacer sin el consentimiento de todos los consocios operaciones particulares de cualquiera especie cuando la sociedad no tuviere un género determinado de comercio.

9. La necesidad de información a la contraparte. La información relevante relativa al contrato y su objeto, debe ser proporcionada entre las partes de manera oportuna, clara, suficiente y completa. Es este tipo de información la que permite la manifestación de la voluntad de las partes en un determinado sentido, ya que el conocimiento de estas condiciones es lo que induce o no a las partes a contratar. ${ }^{52}$ De ahí que será exigible aquella información que sea necesaria para el receptor de la misma al efecto de la formación adecuada de su consentimiento contractual. ${ }^{53}$ Cuando la información es defectuosa se genera un vicio en el consentimiento que induce a un error contractual; pues, como anota Kronman, en estos casos

comercial al asociarse con su subalterno para desarrollar actividades comerciales de las mismas características de aquellas que debía ejecutar por cuenta del empleador, mediante la constitución de algunas sociedades, llegando incluso a operar con éste a través de un tercero, incurre en la causal de despido por incumplimiento grave de sus obligaciones. Por este motivo, no hay despido injustificado, aunque tales hechos no hayan sido previstos por las partes en el contrato de trabajo, tanto porque no corresponde a las partes establecer anticipadamente motivos de exoneración con efecto vinculante, atendido que ésta es materia de orden público, cuanto porque no puede menos que reconocerse que en toda relación entre personas y partes existen siempre exigencias éticas no expresadas pero que son de su esencia y que cuando no son cumplidas hacen imposible la sobrevivencia del lazo (c. 1 y 2). La Corte Suprema desestimó la casación en fallo de fecha 30 de octubre de 2005 (Rol 860/05, PuntoLex).

52 Se suele afirmar que el deber de información descansa sobre dos supuestos. Por una parte en la idea de que normalmente existe asimetría, desigualdad o desequilibrio de conocimientos entre los contratantes, ya que una suele estar mucho más informada que la otra respecto del contrato, sea por razones sociales, económicas, intelectuales o culturales. En este escenario la parte más instruida debe poner en conocimiento de la otra, la inexperta o no profesional, las cuestiones determinantes sobre el contrato. El segundo supuesto es la completa comprensión de los derechos y obligaciones que genera el negocio, con el propósito que las partes puedan aquilatar los riesgos asociados al negocio (cfr. CHINCHILLA IMBETT, Carlos: "El deber de información contractual y sus límites". En Revista de Derecho Privado, Universidad Externado, 21, 2011. pp. 327 ss.; DE LA MAZA GAZMURI, Íñigo: Los límites del deber precontractual de información. Universidad Autónoma de Madrid, Madrid, 2009. pp. 135 ss.; LLOBET I AGUADO, Josep: El deber de información en la formación de los contratos. Marcial Pons, Madrid, 1996. p. 42 y STIGLITZ y STILITZ, ob. cit., punto III.

53 Cfr. MORALES MORENO, Antonio: "El dolo como criterio de imputación al vendedor de los vicios de la cosa". En: Anuario de Derecho Civil, 1982. pp. 631 ss. 
"la información es el antídoto del error". ${ }^{54}$ Por eso las partes, conforme la buena fe, están obligadas a declarar cuanto sea necesario y relevante al contrato. Esta información recaerá, principalmente, sobre los contratantes, el objeto y contenido del contrato, los posibles vicios de la voluntad, los eventuales defectos de la cosa y los efectos del negocio. ${ }^{55}$

10. El imperativo de seguridad y protección en la prestación. Estos deberes se generan especialmente en aquellos servicios prestados con ocasión de un contrato que pueden, provocar un perjuicio a la intergreidad física o síquica de los contratantes o a sus bienes. En este tipo de contratos se trata de preservar incólumes estas esferas jurídicas de las partes, extendiendo la tutela contractual a bienes o intereses que tradicionalmente eran tutelados bajo las reglas de la responsabilidad aquiliana. ${ }^{56}$ Con todo, hay quienes diferencian el deber de protección del deber de seguridad: el primero tendería a preservar la incolumidad de las partes contratantes ante posibles daños en su persona o bienes; en cambio la obligación de seguridad solo protegería la integridad física de una de las partes, el acreedor. ${ }^{57}$ Cualquiera sea el caso ambos deberes emanan fundamentalmente del principio de la buena $\mathrm{fe},{ }^{58} \mathrm{y}$ con independencia de

54 KRONMAN, Anthony: "Mistake, Disclosure, Information, and the Law of Contracts". En: 7 Journal of Legal Studies, 1, 1978. p. 4.

55 Aun cuando normalmente el deber de información se perfila mucho mejor al momento de la formación del contrato, nada impide que se manifieste también durante su ejecución. En este sentido y, por ejemplo, resolvió la Corte de Apelaciones de Santiago que la obligación de pagar de manera íntegra y oportuna las rentas de arrendamiento incluye la obligación tácita de entregar a la arrendadora la información necesaria para el cálculo íntegro y exacto de dichas rentas. En consecuencia, el incumplimiento de esta obligación da derecho a solicitar el término anticipado del contrato (8 de abril de 2016, Inmobiliaria San Juan Limitada con Comercial Taurunum Limitada, 13163-15, MJJ44661).

56 Cfr. MORENO MORE, César: "Apreciaciones críticas sobre el fundamento de los deberes de protección en el ordenamiento jurídico peruano”. En: Ius et Veritas, 49, 2014. p. 224. 57 Por otro lado, los deberes de protección serían recíprocos en el contrato, a diferencia de la obligación, que solamente recaería por sobre el acreedor. Además, el deber de protección comportaría en su mayor parte verdaderas obligaciones de prudencia y diligencia, a diferencia de las obligaciones de seguridad, que siempre, en su correcta acepción, serían obligaciones de resultado (cfr. MORALES HERVIAS, Rómulo: "Los contratos con deberes de protección: a propósito de la vinculación entre el derecho constitucional y el derecho civil". En: Derecho PUCP, Facultad de Derecho, Pontificia Universidad Católica del Perú, 71, 2013. p. 55).

$58 \quad$ BAGALÁ, Pablo: "El deber de seguridad y su impacto en el derecho privado a partir de la aparición del derecho de consumo", disponible en www.pensamientocivil.com. ar y MORALES MORENO, ob. cit., pp. 63 ss. Véase en todo caso la crítica de MORENO HERVIAS, ob. cit., pp. 235 a 236. 
esta eventual precisión, ambas generan los derechos y obligaciones que le son propios, aun cuando no hayan sido explicitadas en el contrato.

11. El rechazo del abuso del derecho. La negación de la posibilidad de abusar de las prerrogativas contractuales se enmarca dentro de la denominada función limitativa de la buena fe. ${ }^{59}$ Esta función esta extensamente aceptada e implica la negación del abuso del derecho, siendo la buena fe el eje central sobre el que se ha estructurado buena parte de la intervención judicial para impedir el ejercicio abusivo de las prerrogativas contractuales. ${ }^{60}$ Esto sucede cuando no existe un interés legítimo para el titular en este ejercicio o en el evento de un desequilibrio flagrante entre el beneficio que obtiene con ello y el perjuicio que con ello causa a la contraparte. ${ }^{61}$ El ejercicio de los derechos emanados de un contrato está subordinado a la regla de la buena fe y la prohibición del abuso del derecho, en el sentido que si una facultad contractual no se ejerce conforme a ella, se configura una actuación ilícita y por lo tanto un incumplimiento contractual. ${ }^{62}$

59 Con todo, algunos piensan que entre abuso de derecho y buena fe existen diferencias conceptuales relevantes. La doctrina del abuso del derecho tendría una función meramente limitativa en el ejercicio de los derechos contractuales, en tanto la buena fe es mucho más sustancial, por cuanto impone complementar o incluso aniquilar las disposiciones contractuales. Por otro lado, la doctrina del abuso del derecho sanciona el ejercicio de un derecho cuando ello es contraria a la finalidad que le confiere el derecho objetivo, requisito que no es necesario para aplicar la buena fe a la actuación contractual (cfr. TISSEYRE, ob. cit., pp. 83 a 85).

60 Cfr. MASSE, Rapport général, Travaux..., ob. cit., pp. 225 y 226. También POPIOTEK, Wojciech,:“Rapport polonais”, Travaux..., ob. cit., pp. 328 y 329.

61 Cfr. OGUZMAN, Kémal y POROY, Reha: "Rapport turc”, Travaux..., ob. cit., p. 352.

62 Ha dicho la Corte de Apelaciones de Santiago, el 10 de octubre de 2008, que "la buena fe constituye, desde luego, un elemento de hermenéutica contractual, derivado del artículo 1546 del Código Civil, conforme al cual las cláusulas de una convención deben interpretarse en armonía con el sentido ético jurídico presente en el orden económico y social imperante". "Es también un principio informador de nuestro ordenamiento jurídico". "Así, en los casos en que el ejercicio de un derecho sobrepasa las exigencias que de él dimanan, se corre el riesgo de incurrir en abuso del derecho o en un enriquecimiento sin causa, entre otros extremos indeseados". "La buena fe se erige, entonces, en un estándar jurídico que no es posible obviar y que, al tiempo de cumplir un contrato, impone tanto al acreedor como al deudor la necesidad de ajustarse a la forma, términos y sentido que se adecuen a su recta ejecución y naturaleza, de manera de evitar la obtención de beneficios, que no tengan justa causa" (Servicios personales a empresas S.A. con Comercial e Inmobiliaria Unimarc S.A., Rol 9433/2004, c. 1). De manera mucho más reciente la ya citada sentencia de la Corte Suprema de 7 de noviembre de 2011, ha dicho que una interpretación del contrato acorde con la buena fe, "conduce indefectiblemente a elucidar que su cumplimiento debe verificarse en los mismos términos como ha sido pactado, de modo que, al constatarse exigencias abusivas o imprevistas de uno de los contratantes, deba necesariamente entenderse incumplida la obligación" (c. 7) (cit., n. 18). 
12. La posibilidad de desestimar una demanda de cumplimiento específico en casos justificados. La cuestión está vinculada muy estrechamente al posible ejercicio abusivo de las prerrogativas contractuales y a la excesiva onerosidad sobreviviniente. Por principio, dada la fuerza obligatoria del contrato, ante su incumplimiento el acreedor tiene el derecho de solicitar su cumplimiento forzado, requiriendo que el deudor, haga o no haga precisamente aquello a lo que en su momento se obligó, debiendo éste cumplir en la forma estipulada en el contrato. No se trata más que de la aplicación de los principios de integridad e identidad de pago ya mencionados. Sin embargo, en casos excepcionales y justificados, la buena fe puede imponer que tal pretensión de cumplimiento específico o en naturaleza deba ser rachazada, especialmente cuando imponga una carga exagerada al deudor en función de las circunstancias imperantes en el momento en que se pide el cumplimiento, debiendo conformarse el acreedor, en estos supuestos, solo con una compensación económica o con otro cumplimiento alternativo. ${ }^{63}$

\section{Los límites de la buena fe en la ejecución del contrato}

Sin lugar a dudas uno de los temas más complejos en esta materia es el de los límites que tiene la buena fe en el marco de la ejecución de los contratos. Trazar una línea divisoria clara entre la aplicación del solo tenor literal del contrato y hacerlo conforme las exigencias que impone su ejecución de buena fe, puede ser una tarea ardua, ya que en ciertos casos podría resultar difícil precisar si lo que una de las partes ejecuta o demanda es simplemente lo que corresponde conforme al texto contractual, o si, por el contrario, tal petición o actuación, amparada en el clausulado contractual, configura una de las hipótesis consideradas como atentatorias contra la buena fe que debe presidir la ejecución del contrato.

$63 \quad$ En este orden de ideas el artículo 7.2.2 de los principios UNIDROIT, señala, en lo pertinente, que si una parte no cumple una obligación distinta a la de pagar una suma de dinero, la otra parte puede reclamar la prestación, a menos que: "(b) la prestación o, en su caso, la ejecución forzosa, sea excesivamente gravosa u onerosa" o "(c) la parte legitimada para recibir la prestación pueda razonablemente obtenerla por otra vía”. En el mismo sentido el artículo 9:102 de los Principios de Derecho Europeo de los Contratos, señala que "(1) La parte perjudicada tiene derecho a reclamar el cumplimiento en forma específica de las obligaciones no pecuniarias y a la reparación del cumplimiento defectuoso de las mismas". "(2) Sin embargo, el cumplimiento en forma específica no podrá obtenerse cuando": "(b) Dicho cumplimiento fuera a provocar en el deudor esfuerzos o gastos irrazonables" o "(d) el perjudicado pueda obtener de manera razonable la prestación por otras vías". 
Ocurre que convergen en un mismo extremo dos obligaciones que son concurrentes: la de cumplir el contrato y la de hacerlo de buena fe, siendo la cuestión difícil la de ponderar si el cumplimiento literal, en función de los hechos y la realidad, viola la obligación de asdemás cumplir de buena fe.

Como punto de partida y a pesar de la enorme trascendencia e influencia de la buena fe en el período de ejecución contractual, erigiéndose con una regla de orden público que no puede ser derogada por los contratantes, no por ello deben pretenderse abolidos los principios esenciales de la contratación y del cumplimiento de las obligaciones.

La autonomía de la voluntad, libertad contractual, la fuerza obligatoria del contrato y los principios de integridad e identidad del pago, son los ejes esenciales sobre los que se construye la eficacia del contrato, y no es razonable extender la buena fe a tal punto que ella se transforme en una herramienta para alterar o modificar el contrato al antojo de una de las partes o del juez que conoce del conflicto contractual. La buena fe, salvo que existan buena razones para ello, no puede alegarse para dejar de lado lo estipulado en el contrato, y ella solamente podrá invocarse para integrarlo donde no hay previsión contractual o lo previsto en el contrato no es armónico, adecuado o coherente con las circunstancias de hecho que rodean su ejecución. ${ }^{64}$ Ella no es un "principio devastador que haga temblar el derecho de los contratos", sino que es un principio complementario que permite en las circunstancias apropiadas y de manera limitada las adaptaciones necesarias en el cumplimiento del contrato. ${ }^{65}$

Debe tenerse en cuenta que a pesar de la potencialidad que puede tener la buena fe en el ámbito contractual, todavía sigue siendo un elemento de integración supletorio de lo claramente establecido en el contrato y solo es aplicable en los especiales casos que sea necesario. Por principio la voluntad expresa y clara de las partes es lo primero; el contrato es obligatorio para ellas y debe ser cumplido al tenor de lo acordado. ${ }^{66}$ En virtud de la buena fe el juez podrá integrarlo estableciendo las obligaciones que conforme a ella se derivan de él y que le son implícitas en razón de su finalidad económica. De la misma forma podrá rechazar cualquier comportamiento o actuación abusiva en función del fin económico del contrato en la forma que ya se ha explicado; pero no puede reescribirlo sólo con base en lo que a él

\footnotetext{
64 Cfr. ORDOQUI, ob. cit., p. 110 y WIEACKER, ob. cit., pp. 29 y 30.

65 PÉRILLEUX, ob. cit., p. 250.

66 Cfr. DANKERS-HAGENAARS, Diana, Rapport Néerlandais, Travaux..., ob. cit., p. 318.
} 
personalmente le pueda parecer más equitativo, justo o idóneo, a menos que se presenten especiales circunstancias que justifiquen su complementación o alteración. Afirmar lo contrario implicaría que el acreedor o el deudor estarían autorizados contractualmente para actuar en contra de la buena fe al intentar evadir lo estipulado. ${ }^{67}$

No debe perderse de vista que en estos casos el contrato está en vías de ejecución, por lo que la buena fe, en esta etapa, está circunscrita a lo que las partes deben dar, hacer o no hacer, en función de lo ya convenido. En un momento anterior, el de la formación del consentimiento, los contratantes, en ejercicio de su libertad contractual ya fijaron de común acuerdo el objeto de su negocio y que el juez no está autorizado para modificar. ${ }^{68}$ En donde sí le cabe intervención al tribunal, es la calificación de si el comportamiento de las partes en la ejecución del contrato está sujeto a las exigencias que impone la buena fe antes mencionadas. ${ }^{69}$

Por eso, y a modo de síntesis, cuando se prescribe que los contratos deben ejecutarse de buena fe, se pretenden básicamente dos cosas: i. que el tribunal pueda imponer nuevos deberes $u$ obligaciones que no estando explícitamente señalados en el contrato, se derivan de su naturaleza, los usos, la costumbre o la ley; y, ii. que rechace y desestime cualquier comportamiento de las partes que, apegado al puro texto contractual, conspire claramente contra su finalidad económica, aspire a ventajas indebidas, viole los actos propios, abuse de prerrogativas o defraude los intereses de la contraparte, pues todo ello contraría el deber de actuar de buena fe.

Si alguna utilidad tiene el intento por enumerar y describir, aunque sea de manérica elemental, las manifestaciones concretas de la buena fe en la ejecución del contrato, es el de precisar aquellas situaciones en las

67

Cfr. OGUZMAN Y POROY, “Rapport turc”, Travaux, n. 12, p. 354.

68 En este sentido, la citada sentencia de la Corte Suprema de 7 de noviembre de 2016, señala que debe rechazarse la impugnación de la sentencia si en ella existe "una correcta aplicación de las cláusulas contractuales que autónomamente convinieron las partes, de suerte que tampoco se divisa ningún abuso susceptible de constatar, y torna impropia la referencia y fundamentación del recurso en el artículo 1546 del Código Civil, el que si bien sirve como herramienta integradora del contrato, por sí misma no es adecuada para dejar sin efecto cláusulas que libre y voluntariamente acordaron los contratantes, cuya extensión y sentido fue correctamente desentrañada por el tribunal, si se recuerda su evidente contenido vinculatorio" (c. 9) (cit., n. 18).

69 Con todo, para algunos la interpretación del contrato como su ejecución, están tan íntimamente ligadas que se trataría de una distinción artificial. Así TYSSEYRE, ob. cit., pp. 262 a 265 . 
que precisamente el tribunal, conociendo del conflicto contractual, puede integrar la convención con base en la buena fe que se deben las partes. Es lo que se puede denominar situaciones contractuales difusas, en las que el puro texto de la convención parece resultar insuficiente para resolver adecuadamente el problema por parte del sentenciador, pues éste tropieza con la realidad de lo acontecido en los hechos. Es en estos casos en los que el tribunal puede reprimir o desestimar cualquier pretensión que apegada a la literalidad del contrato, se aleje de la buena fe en su ejecución. Se trata de que la corrección y la lealtad prevalezcan por sobre la señalada literalidad y que esta última no sirva para amparar ningún comportamiento que, de alguna manera, frustre la finalidad económica perseguida por las partes. "La buena fe excluye que las partes contratantes puedan ejercer sus poderes de un modo formalmente lícito, pero sustancialmente desleal" ${ }^{70}$ Es evidente que las partes deben cumplir con las obligaciones que establece el contrato, sin embargo ello implica cumplir tanto las que fueron establecidas en forma explícita como las que la buena fe permite atribuir a los contratantes; ${ }^{71}$ ya que el ejercicio de una prerrogativa contractual no es puramente discrecional y puede ser sometida al control judicial. ${ }^{72}$

Dentro de lo posible, este es el enfoque que mejor evita las decisiones arbitrarias y subjetivas del tribunal, basadas en su personal entendimiento de la justicia y que sus poderes discrecionales carezcan de cualquier límite. El juez no puede desoír el claro texto del contrato sino en los casos que esté siendo ejecutado formalmente pero en contra de la buena fe. ${ }^{73} \mathrm{Se}$ frenan de esta forma los peligros de la incerteza contractual, pues, de lo contrario, todo contrato podría ser adecuado a las personales convicciones del sentenciador. Por eso, cualquiera de las partes podrá lícitamente ejercer todos de los poderes o derechos que le confiere el texto contractual, para eso se ha otorgado el negocio, pero tal ejercicio debe ser rechazado y considerado como ilícito si configura cualquiera de las ya mencionadas manifestaciones de la buena fe objetiva en la ejecución de los contratos, asumiendo ésta una función limitativa de los derechos ilícitamente ejercidos. ${ }^{74}$

$70 \quad$ GAMARRA, ob. cit., p. 42.

71 Cfr. TISSEYRE, ob. cit., pp. 266 a 268.

72 Cfr. BÉNABENT, Alain: Rapport français, Travaux ..., ob. cit., pp. 297 a 299.

73 Cfr. ORDOQUI, ob. cit., pp. 177, 180 y 218.

74 Cfr. MASSE, ob. cit., p. 225 y TISSEYRE, ob. cit., p. 149. 


\section{Bibliografía}

BAGALÁ, Pablo: "El deber de seguridad y su impacto en el derecho privado a partir de la aparición del derecho de consumo", disponible en www.pensamientocivil.com.ar

BÉNABENT, Alain: Rapport français, La bonne foi, Travaux de l'Association Henri Capitant. Journées lousianeses, Litec, 43, Paris, 1992.

BERNALFANDIÑO, Mariana: "La naturaleza jurídica de la responsabilidad civil derivada de los deberes colaterales de conducta". En: Vniversitas, Bogotá, 126, 2013.

CORRAL TALCIANI, Hernán: Contratos y daños por incumplimiento. Abeledo-Perrot, Santiago, 2010.

CHINCHILLA IMBETT, Carlos: "El deber de información contractual y sus límites". En: Revista de Derecho Privado, Universidad Externado, 21, 2011.

DANKERS-HAGENAARS, Diana: Rapport Néerlandais, Travaux de l'Association Henri Capitant, Journées lousianeses. Litec, 43, Paris, 1992.

DE LA MAZA GAZMURI, Íñigo: Los límites del deber precontractual de información. Universidad Autónoma de Madrid, Madrid, 2009.

DEL VECCHIO, Giorgio: Los principios generales del Derecho, $3^{\mathrm{a}}$. ed.,Bosch, Barcelona, 1971.

DOMÍNGUEZ ÁGUILA, Ramón: "Notas sobre el deber de indemnizar el daño". En: Revista Chilena de Derecho Privado, 5.

DOMÍNGUEZ HIDALGO, Carmen: "Aspectos de la integración del contrato". En: Estudios de Derecho Civil VI, Jornadas Nacionales de Derecho Civil, Olmué, 2010. AbeledoPerrot-LegalPublishing, Santiago, 2011.

DUCCI CLARO, Carlos: "La culpa del acreedor en la responsabilidad contractual”. En: Revista de Derecho y Jurisprudencia, 81.

Fondation pour le Droit Continental y Fundación Fernando Fueyo Laneri, Universidad Diego Portales: El Derecho de los contratos en Latinoamérica. Bases para unos principios de Derecho de los contratos, Carlos Pizarro Wilson (coordinador). Santiago, 2012. 
FUENTES GUIÑEZ, Rodrigo: "El deber de evitar o mitigar el daño". En: Revista de Derecho, Universidad de Concepción, 217-218, 2005.

FUEYO LANERI, Fernando: "La ejecución de buena fe de los contratos como uno de los requisitos del pago". En: Revista de Derecho y Jurisprudencia, 55, 1958.

FUEYO LANERI, Fernando: Instituciones modernas de Derecho Civil. Ed. Jurídica de Chile, Santiago, 1990.

FUEYO LANERI, Fernando: Cumplimiento e incumplimiento de las obligaciones. Santiago, Editorial Jurídica de Chile, 2004.

GAMARRA, Jorge: Buena fe contractual. Fundación de Cultura Universitaria, Montevideo, 2011.

GAMONAL CONTRERAS: Sergio, I Revista de Derecho, Universidad Adolfo Ibáñez, 2004.

JIMÉNEZ VARGAS-MACHUCA, Roxana: "El principio de la buena fe". En: Obligaciones y contratos en los albores del siglo XXI, Homenaje a Roberto López Cabana, Óscar Ameal, director, Abeledo-Perrot, Buenos Aires, 2001.

KRONMAN, Anthony: "Mistake, Disclosure, Information, and the Law of Contracts", 7 Journal of Legal Studies, 1, 1978.

LECLERC, Ginette: "Rapports canadiens", Travaux de l'Association Henri Capitant, Journées lousianeses, Litec, 43, Paris, 1992

LÓPEZ SANTA MARÍA, Jorge: "Sobre la obligación de minimizar los daños en el derecho chileno y comparado". En: Los contratos en el Derecho Privado, Ed. Legis, Bogotá, 2005.

LÓPEZ SANTA MARÍA, Jorge y ELORRIAGA DE BONIS, Fabián: Los contratos. Parte general, Thonson Reuters, 6a ${ }^{\mathrm{a}}$. ed. , Santiago, 2017.

LORENZETTI, Ricardo Luis: Fundamentos de Derecho privado. Código Civil y Comercial de la Nación Argentina, Thomson-Reuters, Buenos Aires, 2016.

LYON PUELMA, Alberto: "Integración e interpretación del contrato". En: Estudios jurídicos en homenaje al profesor Pablo Rodríguez Grez, Ediciones Universidad del Desarrollo, Santiago, 2009. 
LLOBET I AGUADO, Josep: El deber de información en la formación de los contratos. Marcial Pons, Madrid, 1996.

MACKAAY, Ejan: "Good faith in civil law systems. A legal-economic analysis". En: Revista Chilena de Derecho Privado, 18, julio, 2012.

MARTIN, Simon: A propos de l'article 1195 du Code Civil tel que rédigé par l'ordonnance du 10 février 2016, disponible en www.village-justice. com/articles/propos-article-1195-code-civil-tel, 21536.html.

MASSE, Claude: Rapport général. La bonne foi, Travaux de l'Association Henri Capitant, Journées lousianeses, Litec, 43, Paris, 1992.

MENEZES-CORDEIRO, Antonio: "Rapport portugais", La bonne foi, Travaux de l'Association Henri Capitant, Journées lousianeses, Litec, 43, Paris, 1992.

MOMBERG URIBE, Rodrigo: "La revisión del contrato por las partes: El deber de renegociación como efecto de la excesiva onerosidad sobreviniente". En: Revista Chilena de Derecho, 2010, 37, 1.

MORALES MORENO, Antonio: "El dolo como criterio de imputación al vendedor de los vicios de la cosa". En: Anuario de Derecho Civil, 1982.

MORALES HERVIAS, Rómulo: "Los contratos con deberes de protección: a propósito de la vinculación entre el derecho constitucional y el derecho civil”. En: Derecho PUCP, Facultad de Derecho, Pontificia Universidad Católica del Perú, 71, 2013.

MORENO MORE, César: "Apreciaciones críticas sobre el fundamento de los deberes de protección en el ordenamiento jurídico peruano". En: Ius et Veritas, 49, 2014.

OGUZMAN, Kémal y POROY, Reha: "Rapport turc", La bonne foi, Travaux de l'Association Henri Capitant, Journées lousianeses, Litec, 43, Paris, 1992.

ORDOQUI CASTILLA, Gustavo: Buena fe contractual. Grupo Editorial Ibáñez, $3^{\mathrm{a}}$. ed., Bogotá, 2012.

PÉRILLEUX, Jacques: "Rapport belge", La bonne foi, Travaux de l'Association Henri Capitant, Journées lousianeses, Litec, 43, Paris, 1992. 
PIZARRO WILSON, Carlos: "Contra el fatalismo del perjuicio: A propósito del deber de mitigar el daño". En: Revista de Derecho, Universidad Católica de Valparaíso, 41, 2013.

PIZARRO WILSON, Carlos: "El hecho del acreedor en la responsabilidad contractual". En: Estudios de Derecho Civil X, Jornadas Nacionales de Derecho Civil, Valparaíso, 2014. Thomson Reuters, Santiago, 2015, pp. 623 y ss.

POPIOTEK, Wojciech: "Rapport polonaise", La bonne foi, Travaux de l'Association Henri Capitant, Journées lousianeses, Litec, 43, Paris, 1992.

PRADO LÓPEZ, Pamela: La colaboración del acreedor en los contratos civiles. Thomson Reuters, Santiago, 2015.

SAAVEDRA, Francisco: "El principio general de la buena fe". En: Instituciones modernas de Derecho Civil, Homenaje al profesor Fernando Fueyo Leneri. Ed. Jurídica Conosur, Santiago, 1996.

STIGLITZ, Rubén y STIGLITZ, Gabriel: Fallos y doctrina argentina, http://jurisprudencia paratodos.blogspot.cl, 13 de abril de 2013, punto II.

RAMOS PAZOS, René: De las obligaciones. Ed. Jurídica de Chile, Santiago, 1999.

RODRÍGUEZ GREZ, Pablo: Responsabilidad contractual. Santiago, Editorial Jurídica de Chile, 2003.

Tapia Malis, Liat, "La buena fe como mecanismo de integración eficiente", Estudios de Derecho Civil X, Jornadas Nacionales de Derecho Civil, Valparaíso, 2014, Álvaro Vidal et ali, Thomson Reuters, Santiago, 2015, pp. 537 y ss.

TISSEYRE, Sandrine: Le rôle de la bonne foi en droits des contrats. Essai d'analyse á la lumière du droit anglais et du droit européen, Presses Universitaires d'Aix- Marseille, Aix-en Provence, 2012.

VIDAL OLIVARES, Álvaro: "La carga de mitigar las pérdidas del acreedor y su incidencia en el sistema de remedios por incumplimiento". En: Estudios de Derecho Civil III, Jornadas Nacionales de Derecho Civil, Valparaíso, 2007. LegalPublishing, Santiago, 2008.

WIEACKER, Franz: El principio general de la buena fe. Civitas, traducción de José Carro, reimpresión, Madrid, 1986. 